The Polish Journal of the Arts and Culture. New Series 5

(1/2017): 31-50 [ARTICLE]

DOI: $10.4467 / 24506249$ PJ.17.002.6809

\title{
Arab customary law and the modern Western idea of restorative justice
}

\author{
Ewa GórsKa, Jan Bazyli KLAKLA
}

\begin{abstract}
Arab customary conflict resolution and the alternative Western approach to dispute resolution are both the result of a similar way of administering justice - a restorative justice paradigm. Thus, we argue that it is not a new or a strictly western concept given that its fundamental values or even structures have existed in the customary laws of different cultures, like Arab culture, for centuries. In this article, we compare Western restorative justice institutions with the Arab customary conflict resolution process (sulh) used in contemporary Palestine.
\end{abstract}

Keywords: customary law, alternative dispute resolution, sulh, restorative justice

Ewa Górska PhD candidate in Sociology and in Law at Jagiellonian University, holds an MA in Middle Eastern Studies from the same University. Her research interests cover legal pluralism in the Middle East, focusing on Arab customary law and modern Islamic law and it's social and cultural dimensions. In 2014, she was awarded a research grant by the Polish Ministry of Education for a project "Biopolitics and Bioethics in Islamic Countries in the Middle East".

E-MAIL: e.k.gorska@gmail.com

Jan Bazyli KLAKLA PhD candidate in Sociology of Law at Jagiellonian University, holds a BA degree in Comparative Studies of Civilizations earned at the same university. His main area of research includes sociology and anthropology of law, particularly the customary law and the customary-based conflict resolution as well as migration studies. E-MAIL: jan.bazyli.klakla@doctoral.uj.edu.pl 
Analysing the features mentioned in the title, it can be seen that the methods of Arab customary conflict resolution and the alternative Western approach to dispute resolution, especially conferences, are very similar in some respects. Despite some minor differences, they are both the result of a similar approach to the administration of justice - the need for a restitution of the relationships damaged by a conflict within the community, as well as informal social control. In this light, restorative justice is not a new or a strictly western concept given that its fundamental values or even structures have existed in the customary laws of different cultures, like Arab culture, for centuries.

Traditional legal systems are often seen as using "backward", archaic and undemocratic practices standing in contrast, or even in the way of, modernisation and social development. They are considered, especially in the West, to be lacking in democratic accountability mechanisms, legal legitimacy, authority and enforceability, as well as being contrary to social and civil rights and the notions of "justice" attributed to Western legal concepts.

Nevertheless, modern Western mediation procedures like VictimOffender Mediation and conferences are institutions that are strikingly similar and sometimes based on customary solutions used throughout the world. Ideas of restorative justice, which have gained in popularity among Western societies over the last few decades, have been the basis of Arab customary law for at least a few hundred years. Some of the restorative justice traits can even be traced back to pre-Islamic times, some fifteen hundred years ago.

Restorative justice became a new paradigm in Western legal culture in the 1980s, introducing a new way of perceiving and administrating justice. ADR (Alternative Dispute Resolution - ADR) with such institutions as VictimOffender Mediation or conferences are manifestations of this new approach and they have been widely researched in legal literature. But similar analyses of institutions existing outside of the Western culture circle are rarely available and only superficially studied, even though they might serve as examples that provide inspiration for the Western ADR institutions ${ }^{1}$.

One of traditional forms of dispute resolution is the customary Arab sulh process, which might be characterised as a mixed form of mediation and arbitrage. Arab customary law is a remnant of the pre-Islamic legal system that

1 L. Walker, Conferencing: Western Application of Indigenous Peoples' Conflict Resolution Practices, p. 3, [www 01]. H. Zehr, A. Gohar The Little Book of Restorative Fustice, p. 9. J. Haley, Victim-Offender Mediation: Lessons from the Japanese Experience, p. 236. 
was preserved partly in Islamic religious law and mostly in everyday culture and customs. Arab customary law is still in use after hundreds of years despite the changes that have occurred in standards of living and the development of more or less stable and efficient state legal systems. In Palestine, customary law still regulates everyday conflicts, including petty crimes, disputes over land and water, family or marital problems and even life-and-death situations such as accidents, murder and bodily-injury cases. This situation is not unique to Arab countries, although, as in the Balkans and Caucasus, similar legal customs are still practiced alongside the official law - the customs practiced there, called kanun or adat, are very similar to those preserved in Arab societies ${ }^{2}$.

In this article, we compare western restorative justice institutions with the Arab customary conflict resolution process (sulh) used in contemporary Palestine. We chose to focus our study on the occupied Palestinian territories $(\mathrm{oPt})$ for a few reasons. Firstly, in Palestinian society customary law is prominent in everyday live even though the Palestinian Authority and Israeli occupying forces introduced official state legal systems (the usage of customary law was actually perpetuated because of the occupation ${ }^{3}$ ). Secondly, Palestinian customary law is not much different than other customary legal systems in Arab societies; therefore, we feel that we may generalise our research findings from the oPt to talk about informal Arab law and culture. Also, in Palestine the customary dispute resolution procedures are used by different religious denominations, showing the Arab cultural origins of those customs.

Through the analysis of the structure and function of those institutions we initially aim to extract the underlying values, symbolic representations and basic assumptions related to justice and the process of law. Our goal is to see whether the procedures of Arab customary law can be classified as a form of restorative justice. By doing this, we would like to support the argument that the origin of the restorative justice paradigm lays in indigenous traditions ${ }^{4}$. If so, the Western restorative justice idea cannot be seen as "a new

${ }^{2}$ For more see: M. Abu-Nimer, I. Nasser, Forgiveness in The Arab and Islamic Contexts: Between Theology and Practice; C. ten Dam, How to Feud and Rebel: Violence-values among the Chechens and Albanians.

3 Ewa Gorska, Arab Customary Law in Contemporary Palestine - Remnant of the Past or Part of a Modern Arab Society?, in publishing.

4 C. Cunneen, Reviving restorative justice traditions, p. 113. 
theory, a new set of values and a new practical alternative" 5 originally created within Western legal culture. It should be seen instead as a "re-discovery" of an approach that has been present in different legal cultures throughout the ages. Placing the Western concept of restorative justice in a social, cultural and historical context can broaden the perspective of both scholars and practitioners. Although direct references to the specific customary based conflict resolution methods can be found in the restorative justice paradigm ${ }^{6}$, no detailed references to modern Middle Eastern customary practices are present in literature. In this paper, we would also like to take a stance against the position that tends to romanticise and Orientalise customary practices ${ }^{7}$, by not presenting a historical, but rather a modern example of customary based conflict resolution that coexists within a modern state.

\section{Western restorative justice}

Restorative justice is sometimes referred to as "an alternative approach to justice." It emerged in the $1980 \mathrm{os}$ in response to a perceived inefficiency of a legal system based on retributional values ${ }^{8}$. According to the retributional approach, an offence is treated as a wrongdoing against the state and is examined in terms of laws broken and the guilt of the perpetrator. In this approach, judicature is concerned with the determination of guilt and punishment and this process generally involves the state and the perpetrator ${ }^{9}$.

The restorative justice movement aims to change the dominating social responses to crime and wrongdoing ${ }^{10}$. In opposition to the retributive position, restorative justice is based on the view that a crime is an offence against individuals and social relations. As such, it creates an obligation to repair what has been breached by the perpetrator. The judiciary and the administration should engage the victim, perpetrators and the entire community in the search for possible solutions that will enable reparation to be made.

5 G. Maxwell, Crossing Cultural Boundaries: Implementing Restorative fustice in International and Indigenous Contexts, p. 81.

6 C. Cuneen, op.cit., p. 118.

7 Ibidem, p. 116.

8 Although the restorative justice paradigm was originally introduced within common law legal culture, it is now widespread across the globe. Thus, we will be referring in this text to both common law and continental law legal cultures.

9 H. Zehr, A. Gohar, op.cit., pp. 17-20.

${ }^{10} \mathrm{G}$. Johnstone, D. W. van Ness, The meaning of restorative justice, p. 15. 
Restorative justice focuses on the needs of victims, offenders and the community more than on the fault of the perpetrator ${ }^{11}$. Significant attention should be devoted to the injury caused to the victims and to the needs that arise from such an event. Emphasis is on reparation and the subsequent strengthening of the social relations that were ruptured by the perpetrator ${ }^{12}$.

Howard Zehr, one of the creators of restorative justice paradigm distinguishes its three pillars ${ }^{13}$ - the harm combined with an obligation, a commitment to repair the harm and the involvement of all stakeholders. As already mentioned, in the paradigm of restorative justice, an offence is seen as the harm done to people and communities. Criminal wrongs became a public matter concerning the community as a whole. In this way, the victim and the community have to become deeply involved in the process of administration of justice and that involvement has to be wider than in the case of mere personal harm ${ }^{14}$. The interest is directed toward the victim and his or her needs; therefore, it is not punishment that is sought, but a solution that allows maximum compensation for the harm caused. This approach, however, does not limit the harm done exclusively from the victim's perspective, but also considers the angle of the offender and the community. In this way, it expresses a desire to identify the reasons behind the perpetrator's actions, as well as a wish to reintegrate him into the community ${ }^{15}$.

In restorative justice, the harm does not create guilt on the side of the offender, but a commitment to repair the damage caused to the victim and the community. Therefore, the emphasis is put on the responsibility of the perpetrator and his readiness to accept it. On the one hand, this means confidence that the offender will be punished and understand the consequences of his or her actions. On the other hand, it imposes an obligation on the offender to repair the harm caused in the fullest way possible, both in a material and symbolic sense ${ }^{16}$. The response for the offence is geared not towards the stigmatisation of the wrongdoer but towards him recognising a responsibility to make amends for the harm he has caused. This is considered to be the first step towards the perpetrator's reintegration with society ${ }^{17}$.

\footnotetext{
${ }^{11}$ H. Zehr, A. Gohar, op. cit., pp. 11-20.

${ }^{12}$ G. Johnstone, D. W. van Ness, op.cit., p. 7.

${ }^{13}$ H. Zehr, A. Gohar, op. cit., pp. 21-23.

${ }^{14}$ T. Foley, Developing Restorative Justice Jurisprudence. Rethinking Responses to Criminal Wrongdoing, p. 14 .

${ }^{15}$ H. Zehr, A. Gohar, op. cit., p. 21.

${ }^{16}$ Ibidem, p. 22.

${ }^{17}$ G. Johnstone, D. W. van Ness, op.cit., p. 7 .
} 


\section{Western procedures of mediation and conciliation}

Restorative justice promotes the involvement and participation of all stakeholders in the process of achieving justice. The parties directly involved in a crime such as the perpetrator and victim as well as their families and members of the community in which they live all have a role to play in finding a just solution for the existing conflict. With this aim, all the interested parties must create the conditions and opportunities for the free flow of information and multilateral dialogue ${ }^{18}$. In Western culture, where the system of statutory law plays a dominant role, institutions that to a greater or lesser extent implement this idea include mediation (or, more precisely, a specific type known as VOM - Victim-Offender Mediation) and conferences (e.g. family conferences and victim-offender conferences) ${ }^{19}$.

In Western legal culture and in the positive law, the institution of mediation between the offender and victim comes from the United States, where it originated in the early 1970 s. Soon afterwards, the idea was transferred to Western Europe. The specifics of such mediation vary according to country, legal system and local conditions. Nevertheless, a set of common characteristics and typical elements might be distinguished ${ }^{20}$.

First of all, different institutions such as courts, police, prosecutors, probation officers etc. might refer parties to mediation according to the regulations in force in a given country. The referral happens only in cases in which the offender has pleaded guilty. The participation in mediation is voluntary on both sides and therefore requires the approval of both the victim and the perpetrator. In some countries, an indirect form of mediation is practiced, in which the victim wishes to participate in the process but does not wish to meet face to face with the perpetrator. The mediator can act as a go-between to pass the information and the mediation consists of the parties meeting the mediator alone. Nevertheless, this form of VOM is not typical ${ }^{21}$.

\footnotetext{
${ }^{18}$ H. Zehr, A. Gohar, op. cit., p. 22.

${ }^{19}$ P. Wyrick, M. Costanzo, Predictors of Client Participation in Victim-Offender Mediation, p. 254; M. Umbreit, The Development and Impact of Victim-Offender Mediation in the United States, p. 266; J. J. Choi, M. Gilbert, 'Joe everyday, people off the street': a qualitative study on mediators' roles and skills in victim-offender mediation, p. 208; A. Zienkiewicz, Studium mediacji. Od teorii ku praktyce, p. 299.

${ }^{20}$ T. F. Marshall, Restorative Justice on Trial in Britain, p. 217. M. Umbreit, op. cit., pp. 264-265.

${ }^{21}$ T. F. Marshall, op. cit., pp. 219-220.
} 
Mediation is conducted by one or rarely two impartial mediators, often associated in some way with the institutions leading the mediation (e.g. registered on court lists of mediators or working with NGOs conducting VOM).

The mediation usually consists of two phases: a pre-mediation phase, during which the parties prepare to meet face to face and the mediation session itself ${ }^{22}$. A typical mediation session also includes several phases. Firstly, the mediator (or mediators) start the session and define the rules by which both parties and the mediators will act at further stages of the process. Then, the parties have time to express their views, feelings and interests freely and without interruption. During the third phase, interaction takes place between the parties. They may answer questions or address the assertions of the opposing party, exchange information and strive to identify what might constitute the basis for an accord. Agreement is the ultimate result of a successful mediation. It might consist of the obligation of an offender to make amends, both in the form of the payment of a sum of money or performing other tasks imposed by the agreement. The mediation is closed by the mediator summarising what the participants elaborated during the course of the proceedings ${ }^{23}$. The process described above may vary depending on the specific characteristics of criminal procedures in individual countries. The exact meaning of certain legal concepts may be different as well but the general idea behind that institution stays the same.

Conferences form a category of methods for conflict resolution used after the perpetrator admits to having caused harm. Conference groups make decisions by consensus and are conducted by a neutral third party not involved in the decision-making. This party has a position similar to the position of a mediator. We can distinguish between different types of conferences, such as family group conferences, community conferences, restorative conferences or Real Justice conferences which differ among themselves, but also have some characteristics in common ${ }^{24}$.

The conferences involve victims, offenders and the community that the conflict concerns - usually the families of the parties involved and their immediate surroundings. Sometimes, the victim does not want to meet face to face with the perpetrator, in which case the victim's representative can

\footnotetext{
${ }_{22}$ P. Wyrick, M. Costanzo, op.cit., p. 254.

${ }^{23}$ T. F. Marshall, op. cit., pp. 219-220.

${ }^{24}$ L. Walker, op. cit., p. 7.
} 
attend the sessions ${ }^{25}$. There is also a type of conference in which a solution to the conflict is developed within one family, most commonly the offender's. An example of such are the New Zealand family group conferences ${ }^{26}$.

During the conference, all interested parties have the opportunity to discuss the damage and harm that has been done with a focus on how it has affected them. The group then develops a joint idea how the situation might be amended in the best possible way. Such an agreement may be written and signed by the participants of the conference. Sometimes the process ends with a meal shared by all the parties ${ }^{27}$.

On the basis of the above, we can discern certain elements which are characteristic of restorative justice procedures in the West:

1. The definition of a crime as harm against persons and communities

2. The obligation to repair the damage

3. The involvement of all stakeholders in the search for a solution

4. The purpose lies not in punishing the offender, but in amending the harm done to the victim and the community in the best possible way.

In the following part of the article we analyse the Palestinian customary law procedures in comparison to the above-mentioned four elements.

\section{Comparing sulh procedures with Western Res- torative Justice}

We will now analyse the customary Arab mediation in relation to the Western idea of restorative justice. At the beginning, we distinguished certain characteristic points of restorative justice procedures in the West: the definition of the crime as harm against persons and communities; the obligation to repair the damage; the involvement of all stakeholders in the search for a solution. The purpose is not to punish the offender, but to amend the harm done to the victim and the community in the best possible way.

Now, we will describe the procedures of the Palestinian customary conflict resolution in order to try to determine if the above-mentioned four characteristics can be applied to it.

\footnotetext{
${ }^{25}$ Ibidem, p. 7 .

${ }^{26}$ New Zealand Ministry of Social Development, Family Group Conferences, [www 02].

${ }^{27}$ L. Walker, op. cit., p. 8.
} 


\section{Palestinian customary reconciliation proceedings}

Customary reconciliation processes are a traditional, ritualised form of conflict resolution. Nowadays, they are widely practiced in many Arab countries, especially in rural areas. Contemporary Arab customary law is rooted in preIslamic, Arab and Bedouin legal traditions. Pre-Islamic law was the product of a tribal and patriarchal social construction. An individual enjoyed personal security only as long as he was a part of the tribal community (suffice to say, that one of the harshest penalties was expulsion from the tribe). At the same time, the tribe was collectively responsible for the actions of its members ${ }^{28}$.

The informal Arab processes of reconciliation are called sulh, which in Arabic means "Peace, reconciliation or agreement after contention (...); and in the law, it means the compact to give over, or relinquish, contention" ${ }^{29}$. The term sulh is used in Islamic law as well. In shari ' $a$ it is a form of contract - a settlement, if concluded between believers - consisting of an offer and acceptance, binding on personal and community levels and aimed at ending a conflict and restoring peace ${ }^{30}$. The custom of sulh dates back to pre-Islamic times $^{31}$. According to Jabbour ${ }^{32}$, there is evidence of reconciliation processes called sulha in early Semitic writings and Christian scriptures dating to the first century. The custom was preserved in all religious denominations in the Arab community, to date it is still practiced by Muslims, Christians, Druze, and representatives of other minorities in the Middle East ${ }^{33}$.

Customary law, strongly tied to Arab culture and tribal-segmented society, was always important in the Palestinian community. Often treated as an expression of independence and cultural separateness under foreign rules and occupations, it was further developed as a complementary or alternative legal system. Foreign rulers, in their turn, frequently turned a blind eye, if not even supported the local use of customary law because it served their purposes $^{34}$. Also, mediation is still deemed necessary to prevent conflicts within

${ }^{28}$ J. Schacht, Law and Justice, p. 539.

${ }^{29}$ E. W. Lane, Arabic-English Lexicon, p. 1715.

${ }^{30}$ P. J. Bearman, T. Bianquis, C. E. Bosworth, E. van Donzel, W. P. Hinrichs, Cambridge Encyclopaedia of Islam, II (VIII), pp. 846-847.

${ }^{31}$ J. Schacht, op. cit., p. 539.

${ }^{32}$ As cited by D. Pely, Resolving Clan-Based Disputes Using the Sulha, the Traditional Dispute Resolution Process of the Middle East, pp. 80-88.

${ }^{33}$ S. Lang, Sulha Peacemaking and the Politics of Persuasion, p. 53; N. Tsafrir, Arab Customary Law in Israel: Sulha Agreements and Israeli Courts, p. 77.

${ }^{34} \mathrm{R}$. Terris, V. Inoue-Terris, A case study of third world jurisprudence - Palestine: Conflict Resolution and Customary law in Neopatrimonial Society, p. 469. 
and between big families and clans, and to preserve social solidarity in the face of occupation.

Palestinian customary law regulates everyday conflicts involving petty crimes, such as theft, disputes over land and water and other social strife such as family or marital problems. Nowadays, it is even used in cases related to modern environmental disputes like the placement of cellular antennas and high-voltage lines, garbage disposal, connecting premises and buildings for municipal infrastructure (especially in cases involving sawing through pipes or cables on land belonging to other people), the planning of investments and decisions made by local governments. It is also used in serious cases, like homicide and bodily harm ${ }^{35}$.

\section{The sulh procedure in Palestine}

Usually, small, non-violent conflicts are resolved by a single conciliator in direct mediation. In the case of a serious offence, like causing bodily harm, assault, rape or homicide, the mediation is led by a group of conciliators - the jaha. The work of the reconciliatiors is based on two fundamental rules. The first principle is that "reconciliation is the master of rulings" and the second is that the procedures of customary reconciliation are as flexible to the extent that is necessary to serve its purpose - ending the conflict. Therefore, the conciliators can bypass some of the procedures if it helps to reach their goal ${ }^{36}$.

The customary mediation begins when the representative of the offender asks a local member of the reconciliation committee for mediation in the conflict that emerged. Lang ${ }^{37}$ states that within 24 hours after the offence was committed, male relatives of the perpetrator ask the local members of the reconciliation committee to convince the aggrieved party to settle the matter. According to the custom, when asking for the help of the conciliators, the offender shall admit to committing the offence and, along with his family, take responsibility for this act, express regret and a desire for conciliation ${ }^{38}$.

${ }^{35}$ H. Tarabeih, D. Shmueli, R. Khamaisi, Towards the Implementation of Sulha as a Cultural Peacemaking Method for Managing and Resolving Environmental Conflicts among Arab Palestinians in Israel, pp. 50-64.

${ }^{36}$ Birzeit University Institute of Law, Informal fustice, Rule of Law and Dispute Resolution in Palestine. National Report on Field Research Results, p. 75.

${ }^{37}$ S. Lang, op.cit., p. 56.

${ }^{38}$ D. Pely, Resolving..., p. 82. 
At present, these customary forms often come down to a polite phone call from a relative of the offender to a local conciliator ${ }^{39}$.

In the cases of serious crimes, such as homicide or grievous bodily harm, the first task of the mediation committee is to provide a temporary truce (ar. hudna) between the two feuding families. The aim is to prevent bloodshed resulting from the injured party taking revenge. It also allows the victim's family to prepare psychologically and emotionally for entering the reconciliation process ${ }^{40}$. During that time, the reconciliation committee visits all the parties involved to gather facts and investigate. Direct contact between the representatives of both parties is not recommended in such an emotional time; therefore, conciliators act as intermediaries and transmit information between the parties. They maintain neutrality and confidence to avoid the further escalation of conflict ${ }^{41}$.

Sometimes, in the case of grave offences, the offender is evacuated from his place of residence after committing a serious crime ${ }^{42}$. The evacuation has a practical explanation - the need to provide protection to the perpetrator and his relatives from the revenge of the victim's family that may be committed, despite the truce, under the influence of emotions. It also has a symbolic meaning, as it shows humility - it indicates that the family of the offender does not want to exacerbate the conflict more. It helps to respect the principle that during the first period, immediately after the incident there should be no direct contact between the victim and the perpetrator ${ }^{43}$.

In the next stage of the process, the conciliation committee starts to negotiate the terms of settling the conflict and the conditions of the first temporary agreement between the parties. All such agreements, before final reconciliation, are called atwa. They are usually made in cases of serious harm, like homicide or causing bodily harm, when the mediations between the two parties are more complicated ${ }^{44}$. Following the truce and funeral ceremonies, the reconciliation committee gathers to make the agreement. They pay respects to the mourning family and assure them of their readiness to serve as

\footnotetext{
${ }^{39}$ S. Lang, op. cit., p. 56.

$4^{40}$ Ibidem, p. 56.

${ }^{41}$ H. Tarabeih, D. Shmueli, R. Khamaisi, op.cit., p. $5^{2}$.

${ }^{22}$ M. S. Thabit, Al-Qada al-asha'iri ind qaba'il Bir al-Saba [Tribal Law of Tribes of Beersheba]. D. Pely, Resolving..., p. 83 .

${ }^{43}$ S. Lang, op. cit., p. 56; R. Terris, V. Inoue-Terris, op. cit., p. 469.

${ }^{44}$ Birzeit University Institute of Law, op. cit., p. 77; A. M. Hajjah, Al-Urf al-asha'iri fi-l-islah [Tribal Custom in Reconciliation], pp. 177-188.
} 
mediators. The victim's family evaluates the damage and demands compensation.

After negotiating the conditions of the first atwa and payment of the sum, the agreement including all the details and conditions is signed by both parties. Such a document is the basis for the offender's release from jail if he had been arrested for a minor offence - for example causing a car accident $^{45}$. Subsequently, every year the reconciliation committee meets with both parties, convincing them to make a final reconciliation. If they are not ready, the atwa agreement is prolonged for one more year ${ }^{46}$.

When both parties finally decide to reconcile, sometimes after many years of renewing temporary agreements and renegotiating all the conditions, jaha starts the preparations for a final ruling. Agreeing to a final reconciliation also means the parties waiving the right to make decisions, in favour of the reconciliation committee. From this moment, the committee will take all of the circumstances of the case under consideration, but will decide, on its own, about the amount of the final compensation. The parties have to agree that the jaha's adjudication is binding for both of them ${ }^{47}$.

The verdict is presented to both parties as a unanimous decision of the notables. It consists of a ruling on the compensation price (diya), if there is one, and on other conditions of the reconciliation, if need $\mathrm{be}^{4^{8}}$. The parties comply with the reconciliation committee's decision because of social pressure and control, which relies mostly on the notion of honour. Opposing the jaha's judgment would be considered a lack of respect to its members - the most reputable notables from the area ${ }^{49}$.

The offender and his family then organise a ceremony marking the final signing of the reconciliation agreement, called sulha. The closing ceremony is deeply ritualised, with gestures varying from area to area, but usually symbolising forgiveness and the restoration of honour ${ }^{50}$. The organisers invite the inhabitants of the area as well as respected personalities and dignitaries (e.g. politicians, important officials, high-ranking police officers etc.) who are supposed to add state legitimacy to the proceedings. The ceremony,

45 Birzeit University Institute of Law, op. cit., p. 78.

${ }^{4}$ A. M. Hajjah, op. cit., pp. 177-188.

47 D. Pely, Resolving..., p. 77.

${ }^{48}$ A. M. Hajjah, op. cit., pp. 198-199.

${ }^{49}$ D. Pely, Resolving..., p. 77.

${ }^{50}$ H. Tarabeih, D. Shmueli, R. Khamaisi, op. cit., p. 52; D. Pely, Honor: The Sulha's Main Dispute Resolution Tool, p. 77. 
preferably, takes place outdoors - in a public building or in front of it, in the city square or, at times, in the victim's family home ${ }^{51}$.

The final agreement is sealed with a handshake between the parties. Humbly and respectfully, the perpetrator's relatives offer compensation and the victim's family grants forgiveness. The public handshake is a sign for the community that the conflict is finished and the peace between the families will be restored ${ }^{52}$. One of the last elements of the reconciliation ceremony is both families sharing a meal. This should take place publicly and is to be organised by the family of the perpetrator ${ }^{53}$. According to Lang ${ }^{54}$ and Pely ${ }^{55}$, both families should at least share a cup of black Arabic coffee.

The reconciliation ceremony ends with the public reading and signing of the formal reconciliation agreement (waraqat as-sulh) between the parties, by their representatives, several members of the reconciliation committee and some notables. Generally, in the case of murder, the document contains information about who was guilty and to what extent, the nature of the offence, who has paid compensation and to whom, the sum total of the compensation, when it was it paid and in what currency ${ }^{56}$. All conciliatory agreements (atwa and sulha) are also published in an official newspaper at the expense of the offender's family ${ }^{57}$.

It is important to mention that often state law and customary law are used in tandem. In serious cases (like murder, bodily harm etc.) the police, prosecution and state courts carry out official proceedings. Nevertheless, usually while the official court is adjudicating the wrongdoing, offence or crime, the families of the parties negotiate customary reconciliation at the same time. Also the result of such customary reconciliation can largely influence the decision of the state judge. In smaller conflicts the offence or crime might not be reported to the authorities and the families choose to adjudicate it using customary reconciliation only ${ }^{58}$.

\footnotetext{
${ }^{51}$ S. Lang, op. cit., p. 58; A. M. Hajjah, op. cit., pp. 190-191.

${ }^{2}$ H. Tarabeih, D. Shmueli, R. Khamaisi, op. cit., p. 52.

${ }^{53}$ S. Lang, op. cit., p. 6o; D. Pely, Resolving..., p. 85; D. Pely, Honor..., p. 79.

${ }^{54}$ S. Lang, op. cit., p. 60.

${ }^{55}$ D. Pely, Honor..., p. 79.

${ }^{56}$ D. Pely, Resolving..., p. 85 .

${ }^{57}$ Birzeit University Institute of Law, op. cit., pp. 80, 94-97.

${ }^{5}$ Ibidem, pp. 81-84.
} 


\section{The definition of the crime as harm against per- sons and communities}

Already in pre-Islamic times, the Arab society law was subject to a system of tribal and patriarchal social construction. An individual enjoyed personal security, only as long as he was a part of the tribal community (suffice to say, that one of the harshest penalties was expulsion from the tribe - the harsh environment in the Arabian Peninsula meant that it was almost certainly a death sentence). At the same time, the tribe was collectively responsible for the actions of its members. There was no central authority or organised judiciary to adjudicate and execute the law; therefore, the conflicts were usually resolved by negotiations between the parties, sometimes with help of an arbitrator. Most importantly, in that legal culture crimes were understood as torts, meaning a civil wrongful act, leading to a legal dispute between two parties ${ }^{59}$. This has not changed in modern Arab customary law.

The wide range of cases that are dealt with in unofficial Arab courts results from the fact that in customary law, violations of legal norms, murder and bodily harm are treated as torts, not crimes ${ }^{60}$. According to Tsafrir ${ }^{61}$ such acts are prohibited under private law - contrary to most legal systems in the world where they would be classified as crimes and prosecuted ex officio. We see this more as a continuum from public to private, depending on the importance of a wrongdoing. Nonetheless, a crime in Arab reconciliation proceedings is not defined as an offence against the law or state but as a violation against the community and a wrongdoing against another family. It is the damage to the relations and trust between the members of community that is considered a real crime here, not simply a transgression of the rules.

\section{The obligation to repair the damage}

In Palestinian customary law, a violation of law is the source of a liability between the perpetrator and the victim, and the victim or his family may claim damages ${ }^{62}$. This means that the whole sulh proceedings and the investigation carried out by mediators is not designed to detect the culprit and

\footnotetext{
${ }^{59}$ J. Schacht, op. cit., p. 539.

${ }^{60}$ Ibidem, p. 539.

${ }^{61}$ N. Tsafrir, op. cit., pp. $78-79$.

${ }^{62}$ Ibidem, p. 78.
} 
assign blame, but rather to examine the circumstances of the offence and the "scope of the offender's culpability and liability" 3 . During the negotiations, the family of the victim may impose conditions other than financial that must be fulfilled. Sometimes, these conditions may be demeaning to the other party; however, usually the perpetrator's party has to agree if they want reconciliation, especially if the victim's family is influential. The purpose of the whole proceedings is to restore a sense of justice and repair the relations and trust broken by the unlawful act ${ }^{64}$. Accordingly, the group of elders (the jaha) during the negotiations with all the parties involved decide about the best way in which the perpetrator and his relatives can repair the harm done to the victim and community. This usually involves monetary payment to cover the damages.

\section{The involvement of all stakeholders in the search for a solution}

The important difference between the understanding of law in the West and in Arab societies is the notion of the individual in the eyes of the law. The Western concepts of liberalism, modernism and liberal democracy emphasise an approach to the law focused on the state in relation to the rights of the individual $^{65}$. In contrast, Arab customary law does not confer the highest position in the legal system to the rights, obligations and guilt of individuals, but focuses on social solidarity and the duty of the entire clan to bear the burden of the violation of the law committed by one of its members.

The value of tribal affiliations and patriarchal family structures results in the collective approach of the Arab community in everyday life, as well as in legal proceedings. Arab society does not recognise a person as an individual entity, but as a part of a wider family and community group. Therefore, it is never an individual facing conflict or legal action; it is the whole family group. In many cases, the strength of the clan from which any of the persons related to the case comes from is of great significance. In the event of any legal

\footnotetext{
${ }^{63}$ D. Pely, Resolving..., p. 86.

${ }^{64}$ S. Lang, op. cit., p. 53 .

${ }^{65}$ G. Barzilai, Fantasies of Liberalism and Liberal Jurisprudence: State Law, Politics, and the Israeli-Arab-Palestinian Community, pp. 425-451.
} 
proceedings, the problem of guilt and the penalty is less important than the matter of the honour and reputation of the whole clan to which the accused belongs ${ }^{66}$.

\section{The purpose is not to punish the offender, but to amend the harm done to the victim and the community in the best possible way}

The aim of the conciliator and reconciliation committees in Arab customary law is to bridge the gap between the two parties and find a mutually acceptable solution to the conflict, to restore peaceful relations within the community. At the same time, it allows the honour of both parties to be reinstated. From the perspective of Arab society, even matters such as murder do not consist in identifying and sentencing the perpetrator, but in the restoration of normal relations between the two groups estranged by the offence ${ }^{67}$. During the mediation process, all those involved try to determine all the circumstances of the case and find a solution that could be considered fair not only to the parties involved in the conflict, but especially to society as a whole. To achieve such an aim, the customary judge has the flexibility to choose the measures according to the situation ${ }^{68}$.

Customary law is more efficient and quick in resolving legal conflicts as it touches the key problem - the personal relations damaged by the conflict. Customary law serves the function deemed most necessary in this society: it guarantees a compromise solution to the social problem caused by the legal conflict. In Palestinian society, it is more important to resolve the conflict that hinders positive relations between members of the community than indicate the guilty party and punish him or her with sanctions as happens in the course of official judiciary proceedings. The reconciliation procedures are supposed to restore amity between neighbours and strengthen the bond in the community. These reasons were important in ancient times, within tribal social organisations, but are also important nowadays, under the Israeli Occupation. Therefore, customary law has what sociologists of law call social legitimacy - the social acceptance of legal norms. In Palestine, these

\footnotetext{
${ }^{66}$ R. Terris, V. Inoue-Terris, op. cit., p. 462-495.

${ }^{67}$ S. Lang, op. cit., p. 53 .

${ }^{68}$ M. S. Thabit, op. cit.; A. M. Hajjah, op. cit.
} 
norms have a strong moral foundation and were created in the process of social practice by society itself.

\section{Sulh and Conferences}

As the reader may have already noticed, the Palestinian customary sulh proceedings, especially when they concern a grave offence (murder, bodily harm, a serious accident) resemble in their structure and organisation the "conferences" category of conflict resolution, better explained at the beginning of this article.

First of all, both in sulh and conferences, the process of mediation starts with the perpetrator admitting to having committed the offence. Secondly, in both the mediation is conducted by a neutral third participator and the final decision is made by the consensus of all those involved. Thirdly, the conference includes all the parties involved - this also means the members of the families of the victim and the perpetrator and their community. Finally, during the conference all the parties discuss and investigate the damage done by the offensive act, jointly find a solution and usually celebrate the signing of the final agreement by sharing a meal ${ }^{69}$.

The main difference between Arab customary conflict resolution and Western conferences is that the conferences involve the victims and offenders themselves, unless the victim does not wish to take part in the proceedings personally and is represented by someone else ${ }^{70}$. In Palestinian customary law, the victim and offender do not usually take part in the mediation personally, especially in severe cases. They are represented by the appointed notables and elder males from their families who negotiate the solution in the name of the family, not the individuals involved in the original offence. Nevertheless, this comparison shows that sulh can be considered a form of conference mediation or, especially, a community mediation.

\footnotetext{
${ }^{69}$ L. Walker, op. cit., p. 8.

${ }^{70}$ Ibidem, p. 7 .
} 


\section{Bibliography}

1. Abu-Nimer M., Nasser I., Forgiveness in The Arab and Islamic Contexts: Between Theology and Practice, "Journal of Religious Ethics" 41 (3/2013), pp. 474-494.

2. BARzilai G., Fantasies of Liberalism and Liberal furisprudence: State Law, Politics, and the Israeli-Arab-Palestinian Community, "Israel Law Review" 34 (2/200o), pp. 425-451.

3. Birzeit University Institute of Law, Informal fustice, Rule of Law and Dispute Resolution in Palestine. National Report on Field Research Results, 2006.

4. Bosworth C. E., van Donzel E., Heinrichs W. P., Lecomte G., Encyclopaedia of Islam, Brill, Leiden 1997.

5. Choi J. J., Gilbert M., 'Joe everyday, people off the street': A Qualitative Study on Mediators' Roles and Skills in Victim-offender Mediation, "Contemporary Justice Review: Issues in Criminal, Social, and Restorative Justice" 13 (2/2010), pp. 207-227.

6. Cunneen C., Reviving Restorative Justice Traditions [in:] Handbook of Restorative Fustice, G. Johnstone, D. W. van Ness (ed.), Willan Publishing, Portland 2007, pp. 113-131.

7. Foley T., Developing Restorative fustice furisprudence. Rethinking Responses to Criminal Wrongdoing, Ashgate Publishing Company, Burlington 2014.

8. HajJaH A. M., Al-Urf al-sha'ri fi-l-islah الإصلاح في العشائري العرف [Tribal Custom in Reconciliation], Al-Khalil لحشائري العف 2011.

9. HALEy J., Victim-Offender Mediation: Lessons from the Fapanese Experience, "Mediation Quarterly" 12 (3/19950), pp. 233-248.

10. Johnstone G., van Ness D. W., The Meaning of Restorative fustice [in:] Handbook of Restorative fustice, G. Johnstone, D. W. van Ness (ed.), Willan Publishing, Portland 2007, pp. 5-23.

11. Lane E. W., Arabic-English Lexicon, Willams \& Norgate, London 1863.

12. Lang S., Sulha Peacemaking and the Politics of Persuasion, "Journal of Palestine Studies" 31 (3/2002), pp. 52-66.

13. Marshall T. F., Restorative Justice on Trial in Britain, "Mediation Quarterly" 12 (3/1995), pp. 217-231.

14. Maxwell G. Crossing Cultural Boundaries: Implementing Restorative Justice in International and Indigenous Contexts [in:] Restorative fustice: 
From Theory to Practice, H. V. Miller, Emerald Group Publishing Limited, Bingley 2008, pp. 81-95.

15. New Zealand Ministry of Social Development, Family Group Conferences, 2014, [www 02].

16. Pely D., Resolving Clan-Based Disputes Using the Sulha, the Traditional Dispute Resolution Process of the Middle East, "Dispute Resolution Journal" 64 (4/Nov 2008 - Jan 2009), pp. 80-88.

17. Pely D., Honor: The Sulha's Main Dispute Resolution Tool, "Conflict Resolution Quarterly" 28 (1/2010), pp. 67-81.

18. Pely D., When Honor Trumps Basic Needs: The Role of Honor in Deadly Disputes within Israel's Arab Community, "Negotiation Journal" 27, 2011 , pp. 205-225.

19. Pely D., Where East Not Always Meets West: Comparing the Sulha Process to Western-Style Mediation and Arbitration, "Conflict Resolution Quarterly" 28 (4/2011), pp. 427-440.

20. Schacht J., Law and Fustice, [in:] Cambridge Encyclopaedia of Islam, II (VIII), P. J. Bearman, T. Bianquis, C. E. Bosworth, E. van Donzel, W. P. Hinrichs (ed.), E. J. Brill, Leiden 1964.

21. Tarabeih H., Shmueli D., Khamaisi R., Towards the Implementation of Sulha as a Cultural Peacemaking Method for Managing and Resolving Environmental Conflicts among Arab Palestinians in Israel, "Journal of Peacebuilding \& Development" 5 (1/2009), pp. 50-64.

22. TEN DAm C., How to Feud and Rebel: Violence-values among the Chechens and Albanians, "Iran and the Caucasus" 14, 2010, pp. 331-366.

23. Terris R., Inoue-Terris V., A Case Study of Third World Jurisprudence - Palestine: Conflict Resolution and Customary law in Neopatrimonial Society, "Berkeley Journal of International Law" 20, 2002, pp. 462-495.

24. Thabit M. S., Al-Qada al-asha'iri inda qaba'il Bir al-Saba, Filastin القضاء [Tribal Law of Tribes of Beersheba,

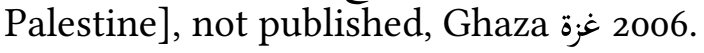

25. Tsafrir N., Arab Customary Law in Israel: Sulha Agreements and Israeli Courts, "Islamic Law and Society" 13 (1/2006), pp. 76-98.

26. UMBreIt M., The Development and Impact of Victim-Offender Mediation in the United States, "Mediation Quarterly" 12 (3/1995), pp. 263-276. 
27. Walker L., Conferencing: Western Application of Indigenous Peoples' Conflict Resolution Practices, paper presented on "Fifth National Conference on Family and Community Violence Prevention”, Los Angeles 2001, pp. 1-25, [www 01].

28. Wyrick P., Costanzo M., Predictors of Client Participation in VictimOffender Mediation, "Mediation Quarterly" 16 (3/1999), pp. 253-267.

29. Zenr H., Gohar A., The Little Book of Restorative Justice, Good Books, New York 2002.

30. Zienkiewicz A., Studum mediacji. Od teorii ku praktyce, Difin, Warszawa 2007.

\section{Internet sources used:}

[www 01] https:/www.researchgate.net/profile/Lorenn_Walker/publication/ 242181355_Conferencing_Western_Application_of_Indigenous_Peoples'_ Conflict_Resolution_Practices/links/55140cbeocf283eeo834a1e3.pdf (access: 16.11.2016)

[www 02] https://www.mvcot.govt.nz/youth-justice/family-group-conferences/ (access: 16.11.2016) 